AL IBTIDA 3 (2): 280-290

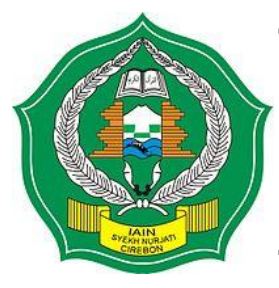

Al Ibtida

ISSN: $2442-5133$

e-ISSN: 2525-7227

Journal homepage: www.syekhnurjati.ac.id/jurnal/index.php/ibtida Journal Email:pgmi@syekhnurjati.ac.id

\title{
PENGARUH KECERDASAN LOGIK MATEMATIK DAN MOTIVASI BELAJAR TERHADAP HASIL BELAJAR MATEMATIKA SISWA MI SE-DKI JAKARTA
}

\author{
Sita Husnul Khotimah \\ Jurusan PGMI STAI AlHikmah Jakarta \\ Email: sita_kh81@yahoo.com \\ Saefudin Zuhri \\ Jurusan PGRA STAI AlHikmah Jakarta \\ Email: saefudinzuhri1979@gmail.com \\ Risan \\ Jurusan PGRA STAI AlHikmah Jakarta \\ Email: risanalfarabi@yahoo.com
}

\begin{abstract}
Abstrak
Pengaruh Kecerdasan Logik Matematik dan Motivasi Belajar Terhadap Hasil Belajar Matematika Siswa MI Se DKI Jakarta. Tujuan dari penelitian ini adalah 1) untuk mengetahui pengaruh kecerdasan logik matematik terhadap hasil belajar matematika, 2) mengetahui pengaruh motivasi belajar terhadap hasil belajar matematika, 3) dan mengetahui pengaruh interaksi antara kecerdasan logic matematik dan motivasi belajar terhadap hasil belajar matematika. Selanjutnya untuk mengetahui pengaruh kecerdasan logik matematik dan motivasi belajar terhadap hasil belajar matematika, metode penelitian yang digunakan adalah metode survey korelasional. Sampel diambil dari $10 \mathrm{MI}$ Se DKI Jakarta, dipilih dengan menggunakan multi stage random sampling. Pengumpulan data dilakukan dengan menggunakan teknik penyebaran angket dan teknik tes. Analisa data dengan menggunakan metode analisis korelasi dan regresi ganda. Uji statistik yang digunakan adalah uji t dan uji F. Analisis data menggunakan teknik korelasi dan regresi (sederhana \& jamak). Dari hasil penelitian ditemukan bahwa: (1) terdapat pengaruh yang berarti antara kecerdasan logik matematik terhadap hasil belajar matematika $(r=0,883$ dan $\hat{Y}$ $\left.=1.276+1,182 \mathrm{X}_{1}\right)$. (2) terdapat pengaruh yang berarti antara motivasi belajar terhadap hasil belajar matematika $\left(r=0,876\right.$ dan $\left.\hat{Y}=0.509+0,138 \mathrm{X}_{2}\right)$. (3) terdapat pengaruh yang berarti antara kecerdasan logik matematik dan motivasi belajar terhadap hasil belajar matematika $\left(r=0,893\right.$ dan $\hat{Y}=0.183+0,062 X_{1}+$ $0,689 \mathrm{X}_{2}$ ).
\end{abstract}

Kata Kunci: Kecerdasan Logik Matematik, Motivasi Belajar, Hasil Belajar Matematika 


\begin{abstract}
Effect of Logical Mathematical Intelligence and Motivation Against Math Student Learning Outcomes MI Se Jakarta. The purpose of this study was 1) to determine the effect of logical mathematical intelligence to mathematics learning outcomes, 2) the effect of learning motivation towards mathematics learning outcomes, 3) to determine the effect of interaction between mathematical logic intelligence and motivation to learn the mathematics learning outcomes. Furthermore, to determine the effect of logical mathematical intelligence and motivation to learn the mathematics learning outcomes, the research method used is correlational survey method. Samples were taken from 10 MI Se Jakarta, selected using multi-stage random sampling. The data collection was done by using questionnaires and test techniques. Analysis of the data by using correlation and multiple regression analysis. The statistical test used was the $t$ test and $F$ test data analysis using correlation and regression techniques (simple \& plural).From the research found that: (1) there is significant influence between intelligence mathematical logic to mathematics learning outcomes $(r=0.883$ and $y=1,276+1,182 X 1)$. (2) there is a significant effect between learning motivation towards mathematics learning outcomes $(r=0.876$ and $y=0509+0,138 \times 2)$. (3) there is a significant effect between logical mathematical intelligence and motivation to learn the mathematics learning outcomes $(r=0.893$ and $y=0183+0,062 X 1+$ $0,689 \times 2)$.
\end{abstract}

Keywords: Intelligence Logic Mathematics, Motivation, Learning Outcomes Mathematics

\title{
PENDAHULUAN
}

Matematika merupakan salah satu bidang studi yang sangat berguna, baik dari segi teoritis maupun dari segi praktis. Pada kenyataannya semua bidang keilmuan maupun sektor kehidupan kita selalu dihadapkan kepada masalah-masalah yang memerlukan matematika sebagai pemecahannya. Contohnya, pada mata pelajaran sejarah memerlukan cara membaca tahun suatu sejarah tertentu, dan kemampuan dasar matematika seorang siswa/i sangat dibutuhkan dalam kehidupan sehari-hari, serta kemampuan matematika siswa dari kelas 1 sampai dengan kelas VI akan diujikan melalui Ujian Nasional (UN) untuk mengukur kemampuan siswa tersebut. Jika sudah mencapai standar nasional pendidikan maka dinyatakan nilai matematika siswa tersebut baik dan jika seluruh mata pelajaran yang di UN kan mendapat nilai di atas standar nasional pendidikan, maka siswa tersebut dinyatakan lulus ujian. Akan tetapi menurut sebagian besar siswa/i, Matematika merupakan salah satu pelajaran yang paling "ditakuti", dan mereka juga kurang termotivasi untuk mengikuti pelajaran matematika apalagi jika materi yang diberikan oleh guru sangat sulit, sehingga 
sebagian besar siswa/i mendapatkan nilai yang kurang baik untuk setiap materi yang sangat sulit.

Faktor-faktor yang dapat mempengaruhi hasil belajar matematika seorang siswa diantaranya adalah faktor eksternal dan faktor internal. Faktor eksternal adalah hal-hal yang berhubungan dengan hasil belajar yang berasal dari luar diri siswa seperti guru, kurikulum, metode, media belajar, sarana belajar, lingkungan dan sebagainya. Sedangkan faktor internal yaitu hal-hal yang berhubungan dengan hasil belajar yang berasal dari dalam diri siswa seperti kecerdasan, minat, bakat, sikap, motivasi, kebiasaan belajar, evaluasi diri dan sebagainya.

Setiap siswa memiliki kecerdasan yang berbeda-beda. Ada siswa yang dapat menciptakan seni visual yang indah. Ada siswa yang mahir di bidang olahraga, mereka mampu membuat gerakan-gerakan fisik yang mengagumkan dan penuh keberanian. Ada siswa yang mampu memainkan alat musik yang bagus sehingga bagi orang yang mendengarkan merasa tersentuh perasaannya. Ada yang merasa tergetar akan tantangan ketelitian matematis. Ada siswa yang suka menulis cerita-cerita dan puisi-puisi. Ada siswa yang mampu menjadi pemimpin yang alami dengan menawarkan model peran yang positif dan pembimbing yang dipercayai oleh teman sekelasnya. Ada juga yang memiliki wawasan personal yang menusuk tentang siapa mereka dan apa kegunaan mereka, sambil mengejar tujuan kehidupan yang utama. Contoh-contoh tersebut memperlihatkan para siswa memiliki kecerdasan dalam bentuk yang berbeda-beda. Tiap siswa itu unik dan semuanya secara individual, menawarkan kontribusi yang berharga bagi kebudayaan manusia.

Motivasi belajar mempunyai arti yang sangat penting dalam proses belajar siswa, karena fungsinya yang mendorong, menggerakkan dan mengarahkan kegiatan belajar siswa. Tujuan (goal) adalah yang menentukan/membatasi tingkah laku organisme itu, dalam hal ini adalah diri siswa atau peserta didik. Sehingga motivasi dapat diartikan sebagai daya penggerak yang telah menjadi aktif. Motivasi juga dapat dikatakan serangkaian usaha untuk menyediakan kondisi-kondisi tertentu sehingga pihak lain mau melakukan sesuatu, dan jika siswa tidak suka, maka siswa akan berusaha untuk meniadakan perasaan tidak suka itu. Menumbuhkan motivasi dalam diri siswa adalah salah satu tahapan penting dalam proses belajar-mengajar, karena motivasi adalah syarat mutlak untuk belajar (Purwanto, 2007: 61).

Berdasarkan latar belakang masalah dan pembatasan masalah, maka diperoleh rumusan masalah sebagai berikut : (1) Apakah terdapat pengaruh kecerdasan logik matematik terhadap hasil belajar matematika siswa (2) Apakah terdapat pengaruh motivasi 
belajar terhadap hasil belajar matematika siswa (3) Apakah terdapat pengaruh kecerdasan logik matematik dan motivasi belajar terhadap hasil belajar matematika.

Berdasarkan rumusan masalah tersebut, maka penelitian ini bertujuan : (1)

Mengetahui pengaruh kecerdasan logik matematik terhadap hasil belajar matematika (2) Mengetahui pengaruh motivasi belajar terhadap hasil belajar matematika (3) Mengetahui pengaruh interaksi kecerdasan logik matematik dan motivasi belajar terhadap hasil belajar matematika. Manfaat penelitian ini adalah Secara teori hasil penelitian ini dapat berguna untuk memberikan sumbangan terhadap perkembangan ilmu pendidikan, khususnya pada mata pelajaran matematika. Dengan meningkatkan kemampuan matematika siswa menjadi lebih baik akan dapat meningkatkan penguasaan materi-materi matematika siswa itu sendiri. Kemampuan matematika sangat penting dalam meningkatkan kemampuan logis, analitis, sistimatis dan kritis siswa. Dengan kemampuan tersebut, dirinya dapat mengembangkan ilmu pengetahuan dalam mensejahterakan hidupnya dan masyarakat.

\section{METODE PENELITIAN}

Tempat pelaksanaan penelitian ini adalah Madrasah Ibtidaiyah se DKI Jakarta dengan sasaran penelitian adalah siswa-siswi kelas V. Penelitian ini dilaksanakan dalam waktu 6 bulan terhitung mulai bulan Juli sampai dengan Desember tahun 2015. Berdasarkan fokus permasalahan dan tujuan yang hendak dicapai, penelitian ini tergolong ke dalam metode survey karena melakukan pengukuran terhadap hal-hal yang nyata seperti mengukur kecerdasan numerik, motivasi belajar dan hasil belajar matematika. Penelitian ini menggunakan teknik analisis korelasional yakni teknik yang dirancang untuk mengetahui seberapa besar pengaruh antara variabel bebas dengan variabel terikat. Dalam penelitian ini terdapat 2 variabel bebas yaitu kecerdasan logik matematik $\left(X_{1}\right)$, motivasi belajar $\left(X_{2}\right)$ dan satu variabel terikat yaitu hasil belajar matematika siswa MI kelas V (Y).

\section{Gambar 1. Konstelasi Permasalahan Penelitian}

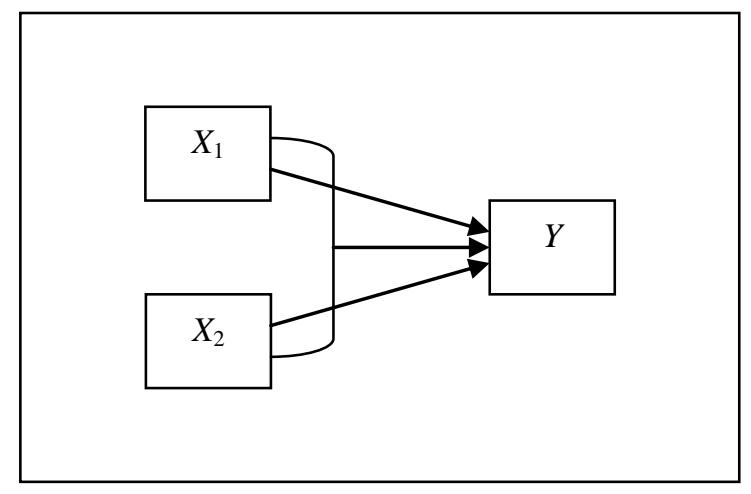


Populasi dalam penelitian ini adalah seluruh siswa/siswi MI kelas V se DKI Jakarta tahun ajaran 2015/2016. Teknik pengambilan sampel dalam penelitian ini menggunakan teknik multi stage random sampling. Sampel yang diambil ditetapkan sebanyak 10 sekolah dari masing-masing wilayah diambil 2 madrasah. Metode pengumpulan data yang digunakan adalah metode survey dan teknik pengumpulan data dalam penelitian ini menggunakan instrumen dalam bentuk kuisioner dan tes. Teknik pengumpulan data untuk variabel kecerdasan logik matematik yaitu dengan menggunakan tes inteligensi berupa tes seri angka yang dikutip dari buku Soal-Soal Inteligensi Tes yang dibuat oleh (Yul Iskandar, 2009).

Teknik pengumpulan data untuk variabel motivasi belajar dengan menggunakan kuisioner motivasi belajar berupa angket motivasi siswa menggunakan skala likert. Teknik pengumpulan data untuk variabel hasil belajar matematika dengan menggunakan tes akademik yang mengandung materi matematika kelas V MI semester I. Jenis tes akademik tersebut terdiri dari 20 soal pilihan ganda. Teknik analisa data menggunakan pengujian korelasi ganda dengan program SPSS 22 untuk mencari seberapa besar hubungan antara hasil belajar Matematika $(\mathrm{Y})$, kecerdasan logik matematik $\left(\mathrm{X}_{1}\right)$ dan motivasi belajar $\left(\mathrm{X}_{2}\right)$.

\section{HASIL DAN PEMBAHASAN}

\section{Hasil Penelitian}

\section{Pengujian Persyaratan Analisis Data}

Sebelum Hipotesis diuji kebenarannya, terlebih dahulu dilakukan pengujian persyaratannya, antara lain mengenai normalitas sampel dan linieritas data variabel penelitian. Pengujian tersebut dilakukan untuk mengetahui data hasil dari penelitian tersebut apakah sudah memenuhi persyaratan atau belum memenuhi persyaratan.

a. Uji Normalitas

Pengujian Normalitas dilakukan pada data variabel kecerdasan logik matematik $\left(\mathrm{X}_{1}\right)$, motivasi belajar $\left(\mathrm{X}_{2}\right)$ sebagai variabel bebas, serta hasil belajar Matematika (Y) sebagai variabel terikat.

Tabel 1. One-Sample Kolmogorov-Smirnov Test

\begin{tabular}{|ll|r|r|r|}
\hline & & & \multicolumn{1}{c|}{$\begin{array}{c}\text { logik } \\
\text { matematik }\end{array}$} & $\begin{array}{c}\text { motivasi } \\
\text { belajar }\end{array}$ \\
\hline & $\mathrm{N}$ & 100 & 100 & 100 \\
Normal & Mean & 22.3800 & 119.7400 & 119.2000 \\
Parameters & Std. Deviation & 6.17067 & 12.94227 & 12.53078 \\
Most Extreme & Absolute & .148 & .103 & .139 \\
Differences & Positive & .148 & .094 & .087
\end{tabular}




\begin{tabular}{|c|c|c|c|}
\hline Negative & -.092 & -.103 & -.139 \\
\hline Kolmogorov-Smirnov Z & 1.050 & .727 & .981 \\
\hline Asymp. Sig. (2-tailed) & .220 & .666 & .291 \\
\hline
\end{tabular}

a. Test distribution is Normal.

b. Calculated from data.

Memperhatikan harga-harga Asymp. Sig (2-tailed) yang ada pada tabel di atas dan sesuai dengan ketentuan seperti tersebut di atas, maka $\mathrm{H}_{0}$ untuk semua variabel yang menyatakan sebaran sampel mengikuti distribusi normal dapat diterima, karena Asymp. Sig (2-tailed) > 0,05. Berdasarkan data tersebut, maka dapat diambil kesimpulan bahwa sebaran skor variabel hasil belajar matematika (Y) Asymp. Sig. (2 tailed) yaitu 0,220, variabel logik matematik $\left(\mathrm{X}_{1}\right)$ Asymp. Sig. (2 tailed) yaitu 0,666 dan motivasi belajar $\left(\mathrm{X}_{2}\right)$ Asymp. Sig. (2 tailed) yaitu 0,291 berasal dari populasi berdistribusi normal.

b. Uji Linieritas

Uji linearitas dipergunakan untuk melihat apakah terdapat data yang linier atau tidak, untuk mengkonfirmasikan apakah sifat linier antara dua variabel yang diidentifikasikan secara teori sesuai atau tidak dengan hasil observasi. Berdasarkan perhitungan didapatkan gambar tabel, sehingga persamaan regresi dalam penelitian ini adalah linier.

Tabel 2. Hasil Uji Linieritas Garis Regresi

ANOVA Table

\begin{tabular}{|c|c|c|c|c|c|c|}
\hline & & $\begin{array}{l}\text { Sum of } \\
\text { Squares }\end{array}$ & df & $\begin{array}{l}\text { Mean } \\
\text { Square }\end{array}$ & $\mathrm{F}$ & Sig. \\
\hline \multirow{3}{*}{$\begin{array}{l}\text { hasil belajar * } \\
\text { motivasi } \\
\text { belajar }\end{array}$} & $\begin{array}{l}\text { Between (Combined) } \\
\text { Groups }\end{array}$ & 1523.964 & 2 & 761.982 & 191.882 & .000 \\
\hline & Within Groups & 385.196 & 97 & 3.971 & & \\
\hline & Total & 1909.160 & 99 & & & \\
\hline
\end{tabular}

Dari hasil diatas bahwa $\mathrm{F}$ hitung $<\mathrm{F}$ table yaitu 191.882 < 3.090 maka garis

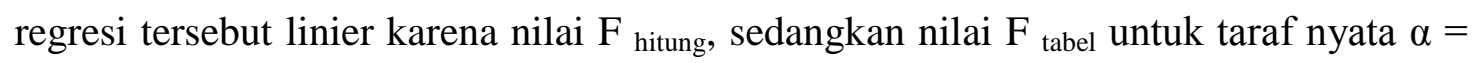
$5 \%(0,05) \mathrm{n}=100$ adalah 3.090 maka $\mathrm{F}$ hitung $<\mathrm{F}_{\text {tabel }}$ yang berarti bahwa garis regresi tersebut adalah linier. 
2. Pengujian Hipotesis dan Penelitian

a. Pengaruh Kecerdasan Logik Matematik $\left(\mathrm{X}_{1}\right)$ dan Motivasi Belajar $\left(\mathrm{X}_{2}\right)$ bersamasama terhadap Hasil Belajar Matmatika (Y)

Tabel 3. ANOVA ganda antara $X_{1}$ dan $X_{2}$ terhadap $Y$

\begin{tabular}{|ll|r|r|r|r|r|}
\hline \multicolumn{1}{|c|}{ Model } & Sum of Squares & Df & Mean Square & \multicolumn{1}{c|}{ F } & Sig. \\
\hline \multirow{2}{*}{1} & Regression & 1523.964 & 2 & 761.982 & 191.882 & $.000^{\text {b }}$ \\
& Residual & 385.196 & 97 & 3.971 & & \\
& Total & 1909.160 & 99 & & & \\
\hline
\end{tabular}

a. Dependent Variable: hasil belajar

b. Predictors: (Constant), kecerdasan logik, motivasi belajar

Analisis korelasi ganda antara $\mathrm{X}_{1}$ dan $\mathrm{X}_{2}$ dengan $\mathrm{Y}$ menghasilkan koefisien korelasi ganda $\left(\mathrm{Ry}_{12}\right)$ sebesar 0,893. Uji keberartian koefisien korelasi ganda menghasilkan nilai $F_{\text {hitung }}$ sebesar 191.882 pada taraf Sig 0,000 yang berarti sangat signifikan. Dengan demikian nilai $191.882>3.090$. Hal ini menunjukkan bahwa ada pengaruh yang signifikan antara kecerdasan logik matematik $\left(\mathrm{X}_{1}\right)$ dan motivasi belajar $\left(\mathrm{X}_{2}\right)$ terhadap hasil belajar matematika $(\mathrm{Y})$.

Penjelasan mengenai penemuan tersebut yaitu: Purwanto (107: 2006) mengungkapkan bahwa ada beberapa faktor internal yang mempengaruhi pencapaian hasil belajar sesorang, yaitu faktor minat, motivasi, inteligensi, kemampuan kognitif, dan kreativitas. Berbicara mengenai faktor inteligensi (kecerdasan), maka ada banyak tipe kecerdasan yang dimiliki oleh manusia, salah satunya kecerdasan logis matematis.

b. Pengaruh antara Kecerdasan Logik Matematik $\left(\mathrm{X}_{1}\right)$ dengan Hasil Belajar Matematika (Y)

Tabel 4. ANOVA ganda antara $\mathrm{X}_{1}$ terhadap $\mathrm{Y}$

\begin{tabular}{|c|c|c|c|c|c|}
\hline \multicolumn{6}{|c|}{ ANOVA $^{a}$} \\
\hline Model & $\begin{array}{l}\text { Sum of } \\
\text { Squares }\end{array}$ & $\mathrm{df}$ & $\begin{array}{l}\text { Mean } \\
\text { Square }\end{array}$ & $\mathrm{F}$ & Sig. \\
\hline $\begin{array}{ll}1 & \text { Regression } \\
& \text { Residual } \\
& \text { Total }\end{array}$ & $\begin{array}{r}1489.246 \\
419.914 \\
1909.160\end{array}$ & $\begin{array}{r}1 \\
98 \\
99\end{array}$ & $\begin{array}{r}1489.246 \\
4.285\end{array}$ & 347.562 & $.000^{\mathrm{b}}$ \\
\hline
\end{tabular}

a. Dependent Variable: hasil belajar

b. Predictors: (Constant), logik matematik

Analisis korelasi antara $\mathrm{X}_{1}$ dengan $\mathrm{Y}$ menghasilkan koefisien korelasi ganda $\left(\mathrm{Ry}_{12}\right)$ sebesar 0,883 . Uji keberartian koefisien korelasi ganda menghasilkan nilai $F_{\text {hitung }}$ sebesar 347,562 pada taraf Sig 0,000 yang berarti sangat signifikan. Hal ini menunjukkan bahwa ada pengaruh yang signifikan antara kecerdasan logik matematik $\left(\mathrm{X}_{1}\right)$ terhadap hasil belajar matematika $(\mathrm{Y})$. 
Penjelasan mengenai penemuan tersebut yaitu: Kecerdasan logis matematis merupakan kecerdasan manusia dalam mengolah angka, berhitung, memecahkan masalah, berfikir logis, berfikir matematis dan kemampuan mengidentifikasi pola hubungan tertentu. Beberapa indikator kecerdasan logis matematis inilah yang membantu manusia mencapai keberhasilan dalam pembelajaran. Kecerdasan logis matematis ini erat kaitannya dengan pelajaran matematika. Jika kecerdasan logis matematis manusia baik maka kemampuan dalam memahami materi pelajaran matematika juga lebih maksimal sehingga diharapkan hasil belajar matematika juga akan maksimal. Purwanto (52: 2011) mengemukakan bahwa "cepat tidaknya dan terpecahkan atau tidaknya suatu masalah tergantung kepada kemampuan inteligensinya".

c. Pengaruh antara Motivasi Belajar $\left(\mathrm{X}_{2}\right)$ dengan Hasil Belajar Matematika (Y)

Tabel 5. ANOVA ganda antara $\mathrm{X}_{2}$ terhadap $\mathrm{Y}$

\begin{tabular}{|l|l|r|r|r|r|}
\hline \multicolumn{1}{|c|}{ Model } & Sum of & \multicolumn{1}{c|}{ ANOVA $^{\text {a }}$} \\
Squares & df & $\begin{array}{c}\text { Mean } \\
\text { Square }\end{array}$ & F & Sig. \\
\hline 1 Regression & 1464.356 & 1 & 1464.356 & 322.629 & $.000^{\mathrm{b}}$ \\
Residual & 444.804 & 98 & 4.539 & & \\
Total & 1909.160 & 99 & & & \\
\hline
\end{tabular}

a. Dependent Variable: hasil belajar

b. Predictors: (Constant), motivasi belajar

Analisis korelasi antara $\mathrm{X}_{2}$ dengan $\mathrm{Y}$ menghasilkan koefisien korelasi ganda $\left(R y_{12}\right)$ sebesar 0,876. Uji keberartian koefisien korelasi ganda menghasilkan nilai $F_{\text {hitung }}$ sebesar 322,629 pada taraf Sig 0,000 yang berarti sangat signifikan. Hal ini menunjukkan bahwa ada pengaruh yang signifikan antara motivasi belajar $\left(\mathrm{X}_{2}\right)$ terhadap hasil belajar matematika (Y).

Penjelasan berdasarkan penemuan tersebut yaitu: hasil belajar matematika dipengaruhi oleh banyak faktor. Agus Suprijono (162: 2010) mengungkapkan bahwa faktor psikologi yang mempengaruhi hasil belajar terdiri dari inteligensi, perhatian, minat, bakat, motivasi, kematangan dan kesiapan. Berdasarkan penelitian Fyan dan Maehr, 'tiga faktor yang mempengaruhi hasil belajar yaitu latar belakang keluarga, kondisi atau konteks sekolah dan motivasi.' Dari beberapa pendapat di atas, maka dapat diketahui bahwa motivasi memegang peranan penting dalam menentukan hasil belajar seseorang. 


\section{SIMPULAN}

1. Terdapat pengaruh yang signifikan kecerdasan logik matematik terhadap hasil belajar matematika siswa. Hal ini berdasarkan pada hasil analisis data yang diperoleh nilai $F_{\text {hitung }}$ $=347,562$ dan sig =0,000. Nilai sig lebih kecil dari 0,05. Maka hipotesis yang diajukan "terdapat pengaruh positif antara Kecerdasan logik matematik dengan hasil belajar matematika" dapat diterima.

2. Terdapat pengaruh yang signifikan motivasi belajar terhadap hasil belajar matematika. Hal ini berdasarkan pada hasil analisis data yang diperoleh nilai $F_{\text {hitung }}=322,629$ dan sig $=0,000$. Nilai sig lebih kecil dari 0,05. Maka hipotesis yang diajukan "terdapat pengaruh positif antara motivasi belajar dengan hasil belajar matematika" dapat diterima.

3. Terdapat pengaruh yang signifikan interaksi kecerdasan logik matematik dan motivasi belajar dengan hasil belajar matematika. Hal ini berdasarkan pada hasil analisis data yang diperoleh $F_{\text {hitung }}=191,882 \mathrm{dan}$ sig $=0,000$. Nilai sig lebih kecil dari 0,05. Maka terdapat pengaruh positif antara kecerdasan logic matematik $\left(X_{1}\right)$ dan motivasi belajar $\left(X_{2}\right)$ secara bersama-sama dengan hasil belajar matematika $(Y)$ ", dapat diterima.

\section{DAFTAR PUSTAKA}

Albrecht, K. (1992). Daya Pikir, Semarang: Dahar Prize.

Arikunto, Suharsimi, Suhardjono, dan Supardi. (2007). Penelitian Tindakan Kelas. Jakarta : PT Bumi Aksara.

Bakri, Suyoto. (2006). Kamus Lengkap bahasa Indonesia, Batam: Karisma Publishing Group.

Campbell, Bruce, Linda Campbell dan Dee Dickinson. (2005). Metode Praktis Pembelajaran Berbasis Multiple Intelligences, Depok: Intuisi Press.

Erman Suherman ,dkk, Strategi Pembelajaran Matematika Kotemporer, Bandung: FMIPA Universitas Pendidikan Indonesia.

Hamalik, Oemar. (2001). Proses Belajar Mengajar, Jakarta: PT Bumi Aksara. (2013). Proses Belajar Mengajar, Jakarta: PT Bumi Aksara.

Hartono. SPSS 16. (2008). Analisis Data Statistika dan Penelitian. Yogyakarta: Pustaka Pelajar.

Iskandar, Yul. Sejak Tahun 1974 Versi Terbaru 2004-2009. Soal-Soal Intelegensi Test, Tangerang : Viano Comm.

Lwin, May, Adam Khoo, Kenneth Lyen, dan Caroline Sim. (2008). How To Multiply Your Child's Intelligence, Cara Mengembangkan Berbagai Komponen Kecerdasan, Jakarta : PT. Indeks.

Nuryanti, Lusi. (2008). Psikologi Anak, Jakarta: PT. Indeks. 
Pahmi

Samsul http://www.academia.edu/9925344/Berfikir_Logis_dan_pembuktian_dengan_induks i_matematika. Diakses pada 7 Desember 2015

Partin, R. L. (2009). Kiat Nyaman Mengajar Di Dalam Kelas Edisi Kedua Jilid 1, Jakarta: PT. Indeks.

Poedjawijatna. (1992). Logika Filsafat Berpikir, Jakarta: PT. Rineka Cipta.

Prawira, P. A. (2012). Psikologi Pendidikan dalam Prespektif Baru, Jogjakarta : Ar-ruzz Media.

Purwanto, Ngalim. (2006). Prinsip-Prinsip dan Teknik Evaluasi Pengajaran. Bandung: Remaja Rosdakarya

Purwanto, Ngalim. (2007). Psikologi Pendidikan. Bandung : PT Remaja Rosdakarya (2011). Psikologi Pendidikan. Bandung: PT Remaja Rosdakarya

Purwanto. (2009). Evaluasi Hasil Belajar, Yogyakarta: Pustaka Pelajar.

Riduwan. (2007). Skala Pengukuran Variable-variabel Penelitian. Bandung: Alfabeta.

Saifullah. (2004). Mencerdaskan Anak (Mengoptimalkan Kecerdasan Intelektual, Emosi dan Spiritual Anak), (Jombang : Lintas Media.

Sardiman, A.M. (2006). Interaksi Dan Motivasi Belajar Mengajar, Jakarta: PT. Grasindo Pusada.

Sardiman, A.M. (2007). Interaksi dan Motivasi Belajar Mengajar, Jakarta : Rajawali Press.

Sarwono, Jonathan. (2014). Riset Skripsi dan Tesis dengan SPSS 22, Jakarta: Elexmedia Komputindo.

Semiawan, Conny R. dan Dra. Djeniah Alim. (2002). Petunjuk Pelayanan dan Pembinaan Kecerdasan Anak Sejak Pranatal Sampai Dengan Usia Sekolah Dasar, Bandung : PT. Remaja Rosdakarya.

Sholihin, U. I. (2013). http://rujukanskripsi.blogspot.co.id/2013/06/kajian-teori-hakikat-hasil Diakses pada 2 Desember 2015

Simplee Ajjah. (2010). http://teorikognitifpiaget.blogspot.com. Diakses pada tanggal 2 Desember 2015

Subarinah, Sri. (2006). Inovasi Pembelajaran Matematiaka SD, DEPDIKNAS.

Sugiyono. (2006). Metode Penelitian Pendidikan. Bandung: Alfabet

Sugiyono. (2007). Statistika untuk Penelitian. Bandung : Alfabeta.

Sukmadinata, N. S. (2003). Landasan Psikologi ProsesPendidikan, Bandung: Remaja Rosdakarya.

Sumarmo, U. (2013). Berfikir dan Disposisi Matematika serta Pembelajarannya, Bandung: FPMIPA UPI.

Suprijono, Agus. (2010). Cooperative Learning. Yogyakarta: Pustaka Pelajar

Surtikanti, dkk. (2012). Pedagogi Khusus Bidang PAUD, Surakarta: FKIP-UMS.

Tadkiroutun, Musfiroh. (2008). Pengembangan Kecerdasan Majemuk, Jakarta: Universitas Terbuka.

Uno, Hamzah B. dan Kuadrat. (2009). Mengelola Kecerdasan dalam Pembelajaran, Jakarta: PT. Bumi Aksara. 
Winkel, W.S. (2004). Psikologi Pengajaran, Yogyakarta: Media Abadi.

Yahaya, Azizi. (2010) http://eprints.utm.my/6264/1/BAB5.pdf

Yaumi, Muhammad. (2012). Pembelajaran Berbasis Multiple Intelligences, Jakarta: PT. Dian Rakyat. 